\title{
JURISPRUDÊNCIA DA TERRA, DIREITOS DA NATUREZA E A ASCENSÃO DA HARMONIA COM A NATUREZA: RUMO AO DIREITO ECOCÊNTRICO?
}

\author{
EARTH JURISPRUDENCE, RIGHTS OF NATURE AND THE ASCENSION OF \\ HARMONY WITH NATURE: TOWARDS THE ECOCENTRIC LAW?
}

\author{
Álisson José Maia Melo \\ Doutor e Mestre em Direito pela Universidade Federal do Ceará (UFC); \\ Professor do Centro Universitário 7 de Setembro (UNI7). \\ E-mail: alisson.melo@gmail.com
}

Recebido em: 29/05/2018

Aprovado em: 26/10/2018

RESUMO: No contexto de crise ambiental e de mudanças climáticas, emergem, especialmente a partir do século XXI, propostas que defendem uma mudança de paradigma de visão do homem na sua relação com a terra. Busca-se avaliar três iniciativas que convergem nesse sentido, a saber: a Jurisprudência da Terra, movimento jurídico-científico de origem anglófona, os direitos da natureza, movimento jurídico-político de origem sul-americana, e a Harmonia com a Natureza, desenvolvida no cenário das Nações Unidas, com o intuito de verificar diferenças, aproximações e a possibilidade de convergência para a introdução do paradigma ecocêntrico no Direito. Adota-se uma metodologia dedutiva, com pesquisa bibliográfica e documental, para examinar separadamente as características dessas correntes jurídicas e, numa abordagem comparativa, críticas na interação entre eles. Conclui-se que, a despeito de uma sutil disputa pela hegemonia entre as duas perspectivas de base, cada qual apresentando suas peculiaridades, a iniciativa neutra e convergente da Harmonia com a Natureza produz resultados favoráveis à integração das manifestações de abordagem ecocêntrica, a indicar a emergência de um novo paradigma jurídico.

Palavras-chave: Jurisprudência da Terra; Direito Selvagem; Direitos da Natureza; Harmonia com a Natureza; Direito Ecocêntrico.

\begin{abstract}
In the context of environmental crisis and climate change, proposals emerge, especially since the beginning of the 21 st century, that advocate a paradigm shift of man's vision in relation to the earth. The purpose of this paper is to evaluate three initiatives that converge in this sense, namely: Earth Jurisprudence, an Anglo-American legal-scientific movement; rights of nature, a juridical-political movement of South American origin; and Harmony with Nature, developed In the United Nations, in order to verify differences, approximations and the possibility of convergence for the introduction of the ecocentric paradigm in Law. A deductive methodology, with bibliographical and documentary research, is adopted to examine separately the characteristics
\end{abstract}


of these legal practices and, in a comparative approach, critics in the interaction between them. It concludes that, despite a subtle dispute over hegemony between the two basic perspectives, the neutral and convergent initiative of Harmony with Nature produces favorable results to the integration of different manifestations of ecocentric approach, indicating the emergence of a new legal paradigm.

Keywords: Earth Jurisprudence; Wild Law; Rights of nature; Harmony with Nature; Ecocentric law.

SUMÁRIO: Introdução; 1 A Jurisprudência da Terra (Earth Jurisprudence) como teoria anglosaxônica do direito ecocêntrico; 2 Os direitos da natureza (derechos de la naturaleza) como elemento político e representativo da visão autóctone a partir do sul; 3 A Harmonia com a Natureza (Harmony with Nature) no contexto internacional: uma tendência para mudanças no paradigma ambiental global; Considerações finais; Referências.

\section{INTRODUÇÃO}

A humanidade apercebe-se, desde 1972 em Estocolmo, porém mais especialmente a partir de 1992 no Rio de Janeiro, que estamos enfrentando desafios ecológicos sem precedentes na História. Várias soluções vêm sendo oferecidas pela comunidade científica e política para contornar o que se pode chamar, para eleger um conceito mais amplo e atual, de mudanças climáticas. Entre tais soluções, algumas delas apostam na mudança ética na relação do homem com a natureza, buscando retornar a um parâmetro de equilíbrio e convivência. Reconhece-se, pela originalidade, o mérito de Christopher Stone (1972, p. 450-501), que já anunciava, nos anos 1970, a necessidade de uma mudança de consciência na relação do homem com o resto da natureza ao defender os direitos das árvores. Nos anos 1980, o americano Tom Regan (1983), a partir de uma visão com inspiração kantiana, sustenta que animais possuam um direito moral básico a um tratamento respeitoso, em virtude do seu valor intrínseco, devendo ser compreendidos como sujeitos morais que experienciam uma vida. Há também a contribuição do chileno Godofredo Stutzin (1984, p. 97-114), para defender os direitos da natureza, como sujeito dotado de personalidade jurídica, numa nova dimensão do Direito a que chama de Direito Ecológico, não mais antropocêntrica, mas baseada numa regra in dubio pro natura. Na mesma década, o alemão Klaus Bosselmann (1985, p. 345-361; 1986, p. 1-22) faz um apelo para a superação do pensamento jurídico antropocêntrico para o ecocêntrico em matéria de proteção do meio ambiente, para sustentar a posição da natureza como sujeito de direitos próprios.

Especialmente a partir do globalizado século XXI, novos caminhos vêm à tona na experiência jurídica mundial, propondo uma mudança de paradigma de conhecimento e de ação em direção à natureza, suportados por pontos de vista que colocam a centralidade na natureza e nos ecossistemas. Busca-se nesta pesquisa investigar a evolução histórica e o conteúdo da Jurisprudência da Terra (Earth Jurisprudence), proposta por cientistas de matriz anglófona, dos direitos da natureza (derechos de la naturaleza), defendida pelo pensamento produzido a partir das experiências das nações sul-americanas, e da Harmonia com a Natureza (Harmony with Nature), iniciativa patrocinada pelas Nações Unidas, com a realização anual de diálogos interativos, relatórios do Secretário-Geral e até mesmo resoluções da Assembleia Geral.

Em que consistem essas três propostas e como se inter-relacionam? Estamos de fato caminhando para um novo paradigma jurídico? O propósito deste artigo é, enquanto são 
apresentados esses três parâmetros de revalorização da compreensão jurídica da natureza, buscar aproximações teóricas e práticas, em prol de uma tentativa de organização dessas construções teóricas e políticas numa unidade de sentido. A hipótese desenvolvida aqui é a de que há um interesse recíproco entre a Jurisprudência da Terra e os direitos da natureza de fortalecer a visão ecocêntrica, e a iniciativa onusiana Harmonia com a Natureza seria o ambiente de diálogo franco e aberto que propiciaria essa convergência em escala global. Secundariamente, busca-se trazer para a literatura jurídica brasileira as discussões em torno dessas correntes; embora os direitos da natureza já venham sendo estudados no contexto do Novo Constitucionalismo Democrático LatinoAmericano, não se verificam menções mais claras em relação aos outros dois movimentos.

Adota-se uma abordagem dedutiva, qualificando-se a pesquisa como exploratória e teórica, com a utilização de extensa pesquisa bibliográfica, de ambos os movimentos jurídicos de base, e documental, em especial decisões judiciais internacionais e resoluções e relatórios da Organização das Nações Unidas. O trabalho está dividido em três seções: na primeira, apresentase a Jurisprudência da Terra, sua origem, fundamentos e características; na segunda, em contraste com a primeira, os direitos da natureza; e, na terceira, a convergência ocasionada pela iniciativa Harmonia com a Natureza. Ao final, nas considerações finais, são contrapostas as principais características das duas correntes jurídicas de base e, em seguida, expostas algumas questões críticas em torno da aproximação dessas correntes jurídico-políticas, bem como de sua repercussão no Direito brasileiro.

\section{A JURISPRUDÊNCIA DA TERRA (EARTH JURISPRUDENCE) COMO TEORIA ANGLO-SAXÔNICA DO DIREITO ECOCÊNTRICO}

Para se fazer uma abordagem com o intuito de identificar mais precisamente a proposta da Jurisprudência da Terra, a partir de um exame das contribuições doutrinárias no tema, trata-se de uma contribuição teórico-científica, de matriz anglófona, conhecida como Earth Jurisprudence ou Wild Law (Direito Selvagem), que busca discutir implicações jurídicas para dar conta de uma mudança de concepção filosófica. Aponta-se como marco dessa necessidade de se pensar um novo direito no limiar do século XXI, com o americano Thomas Berry (1990, p. 151-158), que já indicava, numa perspectiva teológica, a necessidade de mudança de atitudes do ser humano perante o planeta, o que envolveria uma nova comunhão espiritual e mística com a terra, uma estética da Terra que conduzisse a uma sensitividade às suas necessidades e uma economia válida para ela. E isso implicaria reconhecer uma nova capacidade de subjetividade, que incluiria todos os seres.

Contribuição significativa é dada ainda de modo recente pelo sul-africano Cormac Cullinan, com o livro intitulado Wild Law: A Manifesto for Earth Jurisprudence, em 2002. Propõe que a preocupação sobre a questão ambiental não recaia primeiramente sobre o redesenho da legislação, mas, antes de tudo, na necessidade de re-conceituar a ideia de direito a partir de uma perspectiva biocêntrica. De nada adiantariam reformas legislativas se não fosse empreendida uma nova compreensão de que o propósito essencial de governar é dar suporte para que as pessoas possam assumir um papel primordial dentro da comunidade da vida na Terra. A Jurisprudência da Terra corresponde, portanto, a um conjunto de novas teorias ou filosofias de governo coerentes para superar as antigas. (CULLINAN, 2011, p. 8)

Cullinan (2011, p. 9-10) argumenta que a expressão Direito Selvagem pode parecer um contrassenso, já que o Direito se prestaria para organizar, restringir e civilizar a ação humana, enquanto a conotação selvagem conduziria à falta de prévia regulamentação. O propósito, na verdade, é superar essa dicotomia, na busca de integração entre natureza e civilização, e, para tanto, 
seria necessária uma reeducação humana para seu lado selvagem, que aflore criatividade e paixão, o que nos permitiria uma união mais profunda com a natureza. A Jurisprudência da Natureza procura incentivar conexões íntimas entre os povos e a natureza e aprofundar nossa conexão com o lado selvagem de nossa própria natureza, através da proteção da liberdade das comunidades da vida para se autorregularem e assumirem uma função na coevolução contínua do planeta, encorajando a diversidade criativa no lugar da uniformidade impositiva.

Todas as cartas de direitos que contêm vedações à discriminação com base em raça, etnia, cor, gênero, idade ou orientação sexual refletem o propósito do Direito Selvagem ao proteger espaços de florescimento da diversidade. Da mesma forma, leis que garantem o curso saudável de rios, ou que asseveram valor inerente a todos os organismos vivos, estão na linha dessa proposta.

No que concerne aos direitos da Terra, sustenta que o direito mais básico a ser estabelecido é o direito ao bem-estar do planeta, sendo o primeiro princípio da Jurisprudência da Terra a precedência da sobrevivência, saúde e prosperidade da Comunidade como um todo sobre qualquer interesse particular de um indivíduo ou sociedade humana. E, com isso, poderiam ser garantidos os interesses humanos de longo prazo (CULLINAN, 2011, p. 97). Para ele, portanto, a relação jurídica primordial e que está na base da Jurisprudência da Natureza está num vínculo entre o todo e uma parte.

A Jurisprudência da Terra é um campo emergente na Ciência do Direito, que busca aliar uma ética ambiental com a prática jurídica. O propósito maior é buscar uma maior consideração para com a natureza, reconhecendo a interligação dos sistemas naturais do planeta (nele incluído o humano), a existência de um valor inerente à natureza e de direitos correlatos disso, bem como a dependência da humanidade e da vida humana num planeta saudável.

A Jurisprudência da Terra adota dois tipos de reflexões em sua filosofia de base. A primeira, de base cientificista, pode ser encontrada no trabalho de James Lovelock, pesquisador livre que desde o final dos anos 1970 vem sustentando com fortes evidências a chamada hipótese Gaia. Durante suas pesquisas, financiadas pela Nasa, para estudar a existência de vida em Marte, ele e sua equipe observaram que a única explicação viável para a atmosfera altamente improvável da Terra era devido à manipulação diária dessa atmosfera pela superfície, empreendida pela própria vida (LOVELOCK, 2000, p. 6). Posteriormente, pesquisas científicas demonstraram a alta probabilidade da hipótese científica, alcançando o status de teoria. A Teoria Gaia, nomenclatura baseada na deusa grega da Terra, corresponde a uma entidade viva que é do tamanho do planeta, definida como uma entidade complexa envolvendo a biosfera, atmosfera, oceanos e solo da Terra num sistema autopoiético cujo propósito é implementar um ambiente físico-quimicamente viável para a vida no planeta (LOVELOCK, 2000, p. 10).

Ou seja, as ações humanas na Terra, em especial a poluição atmosférica e seus reflexos nos oceanos e no solo, afetam a própria condição de vida no planeta em que vivemos; noutros termos, numa versão fraca da teoria, a Terra é nossa casa e devemos cuidar dela, ou, numa versão forte, os seres humanos são parte integrante de Gaia e não podem mais ignorar seu aspecto biológico em detrimento da supremacia da razão, cuja ruptura com a natureza é a causa da crise ambiental (SIEMEN, 2013, online). Lovelock convida à transição do paradigma antropocentrista para o giro biocêntrico. Aponta que, se a ação humana promover a alteração das condições básicas para a vida na Terra, é mais provável que a vida do planeta, particularmente através de sistemas vivos mais econômicos, sobreviva à espécie humana, pela via da seleção natural. Para que a humanidade possa sobreviver no longo prazo, uma compreensão clara dos limites atribuídos aos processos vitais de Gaia faz-se imprescindível (LOVELOCK, 2000, p. 122). Em trabalhos posteriores, ele utiliza um tom mais crítico e pessimista, em direção a uma reflexão ecológica profunda: 
As ideias que se originam da teoria de Gaia nos colocam em nosso devido lugar como parte do sistema Terra - não somos os proprietários, gerentes, comissários ou pessoas encarregadas. A Terra não evoluiu unicamente para nosso benefício, e quaisquer mudanças que efetuemos nela serão por nossa própria conta e risco. Tal maneira de pensar deixa claro que não temos direitos humanos especiais; somos apenas uma das espécies parceiras no grande empreendimento de Gaia. (LOVELOCK, 2010, p. 22)

Defende, ainda, que a Terra não precisa ser salva, pois ela sempre será capaz de se salvar, e o modo como ela está fazendo é implementando um ambiente mais hostil para combater um mal contagioso, assim como o corpo humano entra em febre para combater uma doença. Embora o ser humano queira salvar o planeta, ele não vislumbra mais tal possibilidade, por considerar já ter sido ultrapassado o ponto sem retorno (LOVELOCK, 2010, p. 31).

A segunda reflexão filosófica que embasa a doutrina da Jurisprudência da Terra, de matriz deontológica, busca dar suporte à tese de que a natureza seria detentora de direitos, em razão do reconhecimento de uma dignidade intrínseca para a natureza. Martha Nussbaum (2008, p. 3-4) sustenta a existência de uma dignidade conferida aos seres sencientes, com base na existência de capacidades inatas desses seres para certas funções tidas como boas, no sentido de ser conferida a oportunidade para que realizem essas funções. Uma dignidade baseada na ideia de florescimento. Toda forma de vida é digna de respeito, havendo um problema de justiça quando um ser não tem a oportunidade de revelar seu valoroso poder, de florescer em sua própria maneira e de ter uma vida com dignidade. No entanto, sua leitura considera a senciência como condição mínima para ter um status moral, fazendo uma crítica quanto à ampliação para a natureza, já que ela não seria particularmente ética ou boa, e os riscos de romancear a discussão (NUSSBAUM, 2008, p. 5).

Numa abordagem mais compreensiva, Christine Korsgaard é uma defensora de uma leitura kantiana sobre a dignidade da natureza. Sua tese possui três argumentos básicos. Primeiramente, os animais devem ser reconhecidos como fins em si mesmos, reconhecendo que há em Kant dois sentidos distintos para "fim em si mesmo": um sentido ativo, que implica a capacidade de alguém legislar para outrem, quer dizer, de que seja respeitada a escolha dessa pessoa para perseguir seu fim; e um sentido passivo, no qual se está obrigado a tratar os fins de alguém, ou pelo menos as coisas que são boas para ela, como absolutamente boas e, nesse aspecto, os animais não seriam diferentes (KORSGAARD, 2012, p. 10 e 14).

Em segundo lugar, temos um dever moral para com os animais, sob o fundamento de que, embora os animais não participem da formação de leis morais, eles não estão submetidos à autoridade delas, nem podem fazer exigências morais aos humanos, num argumento de reciprocidade, pelo fato de possuírem dignidade intrínseca. Eles poderiam obrigar através de suas próprias naturezas, tal como nos obrigamos através da natureza racional da vontade humana (KORSGAARD, 2012, p. 18). Por fim, que os animais seriam titulares de direitos, no sentido de que, embora seja verdade que os seres racionais são os únicos detentores de autoconsciência de sua situação em termos morais e normativos e, com isso, dos quais se deve pressupor um direito de usar o planeta em favor de sua própria manutenção, isso não exclui que outros seres vivos não racionais também não possuam tal direito. Os outros animais são, assim como nós, seres com interesses, a partir dos quais as coisas podem ser boas ou ruins, baseados na necessidade de sobreviver e de prosperar no mesmo planeta (KORSGAARD, 2012, p. 23-24). Os seres humanos, em razão de se autodeterminarem e de estabelecerem as regras morais, não são os únicos seres que importam, mas são aqueles que, em prol dos animais, podem defender a dignidade deles e exigir o dever moral que a eles cabe (KORSGAARD, 2005, p. 36).

Em conclusão, a fusão das ideias conduz à conclusão de que é fundamento dessa corrente teórica o reconhecimento da Terra como centro da comunidade moral (KOONS, 2008, p. 265), 
marcado por uma reflexão e uma consequente tomada de decisão sustentáveis, ou seja, de longo prazo.

Quanto ao desenvolvimento do conteúdo científico-jurídico da Jurisprudência da Terra, uma das principais escolas que estuda o assunto é a Universidade de Barry, nos Estados Unidos, que inclusive coordena o Centro para a Jurisprudência da Terra (Center for Earth Jurisprudence - CEJ). O conceito de interdependência de todas as coisas numa teia da vida, em franca inspiração pela filosofia de Kapra, é um elemento intrínseco, que conduz a uma exigência de humildade e respeito na formulação de leis para a proteção a longo prazo da Terra (SIEMEN, 2008, p. 7). Outras das expoentes da Universidade de Barry é Judith Koons. Ela enumera alguns princípios da Jurisprudência da Terra:

a) princípio da interconectividade: todas as coisas estão dinamicamente conectadas com as demais; (KOONS, 2008, p. 290);

b) princípio do todo-parte: a natureza é compreendida, na perspectiva da complexidade, como a multiplicidade na unidade, e, assim, se uma parte (humana) deve ser considerada moralmente, toda a natureza, portanto, deve ser considerada moralmente (KOONS, 2008, p. 292);

c) princípio da subjetividade: sugere um valor intrínseco da Terra e, com isso, pode-se considerá-la como sujeito de razões morais e jurídicas (KOONS, 2009, p. 58);

d) princípio da comunhão: associada aos princípios da interconectividade e do todo-parte, tal princípio remete a uma responsabilidade relacional, atribuindo-se aos seres humanos, por serem aqueles com capacidades especiais de pensamento e consciência, o ônus de serem os guardiões da comunidade da Terra (KOONS, 2009, p. 62-63); e

e) princípio da diferenciação: em oposição aos modelos modernos de pensamento jurídico, que buscavam a uniformização das condutas e padronização da vida humana, esse princípio reforça o direito à diferença, já não mais sob uma perspectiva apenas humana, mas planetária, conduzindo a uma espécie de democracia da Terra, guiada pelo princípio da subsidiariedade em relação às decisões em nível local (KOONS, 2009, p. 65-66).

Há divergências quanto à forma de abordagem da Jurisprudência da Terra, uma vez que os pesquisadores trazem perspectivas distintas de compreensão. Para alguns, devem ser oferecidas contribuições éticas e de governança com base numa abordagem do ecossistema. Por outro lado, defensores dos direitos dos animais preferem, à abordagem ecocêntrica, porque haveria na sua base um viés utilitarista, a proteção baseada na senciência dos seres. Já outros filósofos ampliam as considerações para todos os seres vivos, enquanto numa versão mais ampla há os que dão suporte para toda a natureza viva e não-viva. (KOONS, 2008, p. 292-293).

Em termos de aplicabilidade jurídica, a Jurisprudência da Terra deve servir como suporte para uma análise de impactos dos ordenamentos jurídicos na saúde e viabilidade da comunidade da Terra (SIEMEN, 2008, p. 2). Para Koons (2009), podem ser extraídos dos princípios da Jurisprudência da Terra a defesa da personalidade da natureza, viva e não-viva, conferindo-lhe suporte para ser detentora de direitos, a responsabilidade humana perante à comunidade da Terra, mediante o recurso ao instituto do administrador ou defensor público ou do representante da Natureza, e o princípio da sustentabilidade, a garantia de acesso à Terra para as presentes e futuras gerações humanas e não humanas.

Outro dos movimentos dentro dessa teoria geral do Direito é o reconhecimento de direitos para a natureza. Na Universidade de Adelaide, na Austrália, há outra escola de pensamento da Jurisprudência da Terra, capitaneada por Peter Burdon. Seguindo a linha de pensamento fundada por Thomas Berry, Burdon (2010) considera a importância do reconhecimento das relações jurídicas bilaterais com a natureza através da existência de direitos para todos os seres, por ser uma estratégia jurídica eficaz para proteger a natureza. Ademais, ele reconhece que a Jurisprudência da 
Terra melhor se aproxima como uma nova teoria do Direito Natural, ao que ele denomina de Grande Direito, mas com um olhar não mais antropocêntrico, porém ecocêntrico (BURDON, 2012, p. 33-35). Isso porque ele serviria de fundamento de legitimidade para a elaboração de um novo Direito positivo, que considerasse os princípios da Jurisprudência da Terra acima assinalados.

\section{OS DIREITOS DA NATUREZA (DERECHOS DE LA NATURALEZA) COMO ELEMENTO POLÍTICO E REPRESENTATIVO DA VISÃO AUTÓCTONE A PARTIR DO SUL}

Em contraponto à Jurisprudência da Terra, o que aqui se denomina de direitos da natureza é, antes de ser um movimento científico, em parte organizado, em favor de uma agenda ecocêntrica, um conjunto difuso de movimentos políticos que deitam suas origens na América Latina. Derivado diretamente do Novo Constitucionalismo Democrático Latino-Americano, os direitos da natureza, suportados por costumes jurídicos não escritos, se positivaram nas recentes Constituições do Equador (2008) e da Bolívia (2009).

O Novo Constitucionalismo Democrático Latino-Americano é uma iniciativa políticojurídica sem pais (sin padres) (VICIANO PASTOR; MARTÍNEZ DALMAU, 2011, p. 11), de forte conotação descolonial e emancipatória - "visa resgatar os sujeitos negados, enquanto protagonistas dentro do Estado e de suas vidas, incluindo-se nesse rol de sujeitos a própria natureza" (MARTINS; TYBUSCH; MORELLO, 2017, p. 100) —, que busca reavivar e valorizar os conhecimentos ancestrais dos povos tradicionais, a partir da cosmovisão indígena. Recupera a origem revolucionária do constitucionalismo, estabelecendo mecanismos para realizar a emancipação e avanço dos povos através da Constituição como fundamento último do poder (VICIANO PASTOR; MARTÍNEZ DALMAU, 2010, p. 4). Entre suas características, o Novo Constitucionalismo Democrático Latino-Americano tem como elementos materiais a recuperação da legitimidade soberana com o incremento de fórmulas de participação direta da população na deliberação democrática, a previsão de uma profusa carta de direitos, incluindo direitos da natureza, e a integração de setores historicamente marginalizados, principalmente os povos indígenas (VICIANO PASTOR; MARTÍNEZ DALMAU, 2010, p. 19-22).

$\mathrm{Na}$ base axiológica desse movimento, encontra-se uma cosmovisão própria do indígena, denominada de bem-viver. Tal filosofia deita origens no sumak kawsay quéchua (traduzido como buen vivir) e do suma qamaña aymara (traduzido como vivir bien), que tem como um de seus pressupostos a harmonia com a natureza, e o respeito à existência e à personalidade dela, compreendida como Mãe Terra ou Pachamama. Para Brandão (2015, p. 149 e 154), “[o] Sumak Kawsay surge como uma resposta da cosmovisão indígena que visa a integrar o homem e a natureza de forma respeitosa" e, no mesmo sentido, “o Bem-Viver não instrumentaliza a natureza, pelo contrário, inter-relaciona os seres humanos com a biosfera, criando uma solidariedade vinculante entre pessoa-sociedade-natureza". Diferenciando-se do "viver melhor" de matriz colonizadora e eurocêntrica, o bem-viver estabelece uma conexão com todas as coisas sem hierarquias, e significa complementar e compartilhar sem competir, viver em harmonia entre as pessoas e com a natureza (HUANACUNI MAMANI, 2010, p. 21-22). Essa cosmovisão comum conduz à transição de paradigmas filosóficos na América Latina:

O modo diferenciado como os povos indígenas interagem com o meio ambiente é fundamental na superação do antropocentrismo cartesiano como paradigma ambiental e na ascensão de modelos não-antropocêntricos mediante o reconhecimento da natureza como sujeito de direitos, em especial o modelo ecocêntrico. (MORAES; MARQUES JÚNIOR, 2013, p. 53) 
Como assinala Huanacuni Mamani (2010, p. 19), as nações aymara e quéchua concebem a Pachamama como a energia ou força telúrica e é uma das fontes de geração de toda forma de existência. A partir dessa cosmovisão, somos todos filhos da Mãe Terra, numa grande relação de parentesco de todas as coisas vivas; portanto, não existe o outro, mas há somente o "nós", e as decisões a serem tomadas devem tomar em primeiro lugar a Mãe Terra - e o indivíduo somente em último lugar —, da qual pertencemos e estabelecemos uma relação implícita de responsabilidade (HUANACUNI MAMANI, 2010, p. 48-49). Há um vínculo umbilical entre os povos indígenas e a questão territorial.

Houtart (2011, p. 67), acerca do tema, obtempera que a relação com a natureza tem um lugar privilegiado na visão do bem-viver e, sendo a natureza um ente integral, do qual o homem é parte, que preocupar-se com a humanidade significa em primeiro lugar defender a terra e estabelecer a harmonia entre a natureza e os seres humanos, o que implicaria o respeito a todo o entorno natural. $\mathrm{O}$ bem-viver proporia uma mudança nas práticas econômicas e culturais por um imperativo ético.

Por outro lado, a Mãe Terra também é vista, na visão indígena, de um ponto de vista aparentemente antropomórfico, como uma deusa com personalidade. Para Zaffaroni (2012, p. 118), Pachamama é a natureza e se ofende quando seus filhos são maltratados; não impede a caça e a pesca, mas sim a depredação, como boa reguladora da vida de todos que nela estamos. Mas, na verdade, trata-se de um arquétipo presente em vários povos originários ao redor do planeta (como Gaia, por exemplo).

A Constituição do Equador (2008, p. 21), país onde se adota a denominação Direitos de Pachamama, dispõe que a natureza será sujeito daqueles direitos reconhecidos pela Constituição (art. 10, segundo parágrafo). Mais à frente, são arrolados os direitos da natureza:

Art. 71. A natureza ou Pachamama, onde se reproduz e se realiza a vida, tem direito a que se respeite integralmente sua existência e a manutenção e regeneração de seus ciclos vitais, estrutura, funções e processos evolutivos.

Toda pessoa, comunidade, povo ou nacionalidade poderá exigir à autoridade pública o cumprimento dos direitos da natureza. Para aplicar e interpretar esses direitos devem ser observados os princípios estabelecidos na Constituição, no que for compatível.

O Estado incentivará as pessoas naturais e jurídicas e os grupos para que protejam a natureza e promoverá o respeito a todos os elementos que foram um ecossistema.

Art. 72. A natureza tem direito à restauração. Essa restauração será independente da obrigação que têm o Estado e as pessoas naturais ou jurídicas de indenizar os indivíduos e grupos que dependam dos sistemas naturais afetados.

Nos casos de impacto ambiental grave ou permanente, incluídos os ocasionados pela exploração dos recursos naturais não renováveis, o Estado estabelecerá os mecanismos mais eficazes para alcançar a restauração e adotará as medidas adequadas para eliminar ou mitigar as consequências ambientais nocivas.

Art. 73. O Estado adotará medidas de precaução e restrição para as atividades que possam conduzir à extinção das espécies, a destruição de ecossistemas ou a alteração permanente dos ciclos naturais.

É proibida a introdução de organismos e material orgânico e inorgânico que possa alterar de maneira definitiva o patrimônio genético nacional.

Art. 74. As pessoas, comunidades, povos e nacionalidades terão direito a beneficiar-se do ambiente e das riquezas naturais que lhes permitam o bem viver (buen vivir). (ECUADOR, 2008, p. 52) 
Gudynas (2009, p. 36) observa que o rol dos direitos da natureza deve ser interpretado juntamente com outras partes da Constituição do Equador, como os direitos do bem-viver — no caso, o direito ao ambiente sadio (arts. 14 e 15) —, a descrição do regime de desenvolvimento em convivência harmônica com a natureza (art. 275, terceiro parágrafo), tendo como um de seus objetivos recuperar e conservar a natureza e manter um ambiente sadio e sustentável de modo a garantir às pessoas e coletividades acesso equitativo, permanente e de qualidade à água, ar e solo e aos benefícios do subsolo e do patrimônio natural (art. 276, item 4), e uma elaboração mais detalhada do regime do bem-viver, com o reconhecimento de princípios ambientais (art. 395).

Para Acosta (2010b, p. 18), dotar constituições de direitos da natureza traduz parte de um processo político centenário de ampliação dos sujeitos de direitos, desde os escravos a mulheres e crianças; no caso dos direitos da natureza, assevera o seguinte:

O principal dos direitos da natureza é resgatar o 'direito de existir' dos próprios seres humanos. Sua vigência, como proposta política e não somente jurídica, suscita profundas mudanças. Isso nos obriga a transitar do antropocentrismo atual ao biocentrismo. Talvez devêssemos falar, de forma mais correta, de um sociobiocentrismo que teria que se concretizar em um novo socialismo de novo tipo. Mudança que exige um processo contínuo e plural. (ACOSTA, 2012, p. 202)

Mas, em tom crítico, entende que o reconhecimento jurídico é insuficiente se não houver um esforço político de reconhecimento. Desenvolvendo essa tese, sustenta que a natureza vale por si mesma, representando, para ele, uma visão biocêntrica; os direitos da natureza, aos quais prefere denominar de direitos ecológicos em contraposição aos direitos ambientais, não defendem uma natureza intocada, mas sim que sejam mantidos e respeitados os sistemas de vida, ecossistemas e coletividades, e demandam um novo tipo de cidadania, do tipo plural e socioambiental (ACOSTA, 2010b, p. 20).

A menção a Pachamama, no art. 71, não deve ser compreendido de forma restritiva, como um reconhecimento exclusivo da cosmovisão quéchua. Deve-se incorporar uma concepção plural de Pachamama, na reflexão de Gudynas (2011, p. 267), junto a outras concepções do entorno e dentro de um relativismo cultural, pois cada povo originário não apenas define o meio ambiente de uma forma, mas que também possui suas próprias particularidades sobre os usos corretos e aceitos da natureza, sem implicar que uma é necessariamente melhor do que outra.

Já a Constituição da Bolívia (2009), país onde se prefere a denominação Derechos de la Madre Tierra, por sua vez, não traça direitos da natureza propriamente ditos, mas há, em seus dispositivos, claros indícios da mesma tendência (SANTAMARÍA, 2017, p. 83). No capítulo que trata dos direitos sociais e econômicos, dedica a primeira seção ao direito ao meio ambiente, destacando o seguinte:

Artigo 33. As pessoas têm direito a um meio ambiente saudável, protegido e equilibrado. $\mathrm{O}$ exercício desse direito deve permitir aos indivíduos e coletividades das presentes e futuras gerações, além de outros seres vivos, desenvolver-se de maneira normal e permanente.

Artigo 34. Qualquer pessoa, a título individual ou em representação de uma coletividade, está facultada a exercitar as ações legais em defesa do direito ao meio ambiente, sem prejuízo da obrigação das instituições públicas de atuarem de ofício frente aos atentados contra o meio ambiente. (BOLIVIA, 2009, p. 11, grifos nossos)

Uma leitura imediatista do texto conduziria à compreensão de ter o constituinte na Bolívia adotado uma visão da natureza como direitos fundamentais de terceira dimensão (MORAES; MARQUES JÚNIOR, 2013, p. 61). Entretanto, na análise de Zaffaroni (2012, p. 110), a Constituição boliviana, embora trate a questão ambiental como um direito social e econômico, 
inclinando-se a uma tendência ambientalista, não deixa de referir-se a outros seres vivos, o que, na visão dele, importaria reconhecer-lhes direitos.

A ação popular, com procedimento equivalente da ação de amparo constitucional, está prevista no artigo 135 da Constituição, que pode ser utilizada por qualquer pessoa contra todo ato ou omissão de autoridades ou de pessoas individuais ou coletivas que violem ou ameacem violar direitos e interesses coletivos relacionados, entre outros, com o meio ambiente (BOLIVIA, 2009, p. 30). Para Zaffaroni (2012, p. 110), trata-se uma consequência inevitável do reconhecimento da personalidade da própria natureza.

Mas em outras passagens, a Constituição remete à noção de harmonia com a natureza. No capítulo sobre as relações internacionais, a negociação, assinatura e ratificação de tratados internacionais será regida pelo princípio da harmonia com a natureza, defesa da biodiversidade e proibição de formas de apropriação privada do meio ambiente (artigo 255, inciso II, item 7) (BOLIVIA, 2009, 58-59). No título que trata da organização econômica do Estado, um dos aspectos da chamada economia plural é a industrialização dos recursos naturais como forma de superar a dependência econômica nas exportações de matérias primas através de uma economia de base produtiva que considere o desenvolvimento sustentável em harmonia com a natureza (artigo 311, inciso II, item 3) (BOLIVIA, 2009, p. 77). No capítulo sobre terra e território, reconhece a integralidade do território indígena originário campesino, que inclui a faculdade de aplicar as normas próprias dessas comunidades, com base em estruturas de representação que levem em consideração a convivência harmônica com a natureza (artigo 403) (BOLIVIA, 2009, p. 95). Santamaría (2017, p. 84), interpretando sistematicamente a Constituição boliviana a partir de um pensamento crítico, arremata que a noção de harmonia rompe com o dualismo hegemônico hierarquia-dominação propondo a relação respeito-igual consideração.

Do ponto de vista de Gudynas (2009, p. 38), reconhecer os direitos da natureza, independente das valorações humanas, é dar um passo muito maior do que o que vinha sendo feito até então nas Constituições latino-americanas, que estabeleciam o direito ao meio ambiente ecologicamente equilibrado como direitos de terceira geração. Prossegue sustentando que se admite que a natureza possui valores intrínsecos que resvalam nos componentes ético, moral e político, conducentes à ecologia profunda. Como assinala Zaffaroni (2012, p. 111), que reconhece nessas constituições do constitucionalismo andino um grande salto do ambientalismo para a ecologia profunda ou um "ecologismo constitucional", resta claro que nas duas constituições a natureza assume o papel de sujeito de direitos, expressamente no Equador e tacitamente na Bolívia, mas tal diferenciação não implica efeitos diferentes, pois o sistema jurídico fornece o instrumental processual necessário para a defesa da natureza por qualquer pessoa. A dignidade humana não desaparece, mas passa a dividir sua importância com a dignidade da natureza.

Talvez se a pauta política dos direitos da natureza tivesse remanescido exclusivamente no cenário constitucional, talvez ainda estivéssemos discutindo a questão da eficácia desses direitos em um contexto de implementação de direitos fundamentais e desacreditação dos institutos de proteção dos direitos da natureza. Como afirma Brandão (2015, p. 155):

Mas, obviamente, não basta positivar o Sumak Kawsay nessas Constituições. Há necessidade de desenvolvimento que desdobre a filosofia do Bem-viver e da Pachamama em diversos dispositivos dessas novas experiências constitucionais, notadamente na questão do desenvolvimento econômico, recursos naturais e da propriedade.

Com efeito, em 2008, a Secretaria Nacional de Planejamento e Desenvolvimento do Equador (SENPLADES) elaborou o Plan Nacional para el Buen Vivir 2009-2013, que busca contemplar um novo modo de geração de riqueza e redistribuição para o bem-viver. São estratégias do plano a democratização dos meios de produção, a redistribuição da riqueza e a diversificação 
das formas de propriedade e organização, a transformação do padrão de especialização da economia, através da substituição seletiva de importações, o aumento da produtividade real e diversificação da matriz de exportação, a inserção estratégica e soberana no mundo e a integração latino-americana, a transformação da educação superior e transferência do conhecimento através da ciência, tecnologia e inovação, a conectividade e as telecomunicações para a sociedade da informação e do conhecimento, a mudança da matriz energética, o investimento para o bem-viver no marco de uma macroeconomia sustentável, a inclusão, proteção social solidária e garantia de direitos, a sustentabilidade, conservação e conhecimento do patrimônio natural e o fomento do turismo comunitário, o desenvolvimento e planejamento territorial, desconcentração e descentralização, e o poder cidadão e protagonismo social (EQUADOR, 2009, p. 59-72). Em 2013, um segundo plano nacional foi elaborado.

Na Bolívia, por sua vez, em 2012 foi aprovada Ley Marco de La Madre Tierra y Desarrollo Integral para Vivir Bien. Adotando a nomenclatura de desenvolvimento integral para contrapor ao de simples desenvolvimento, que poderia ensejar conotações exclusivamente econômicas, o propósito é estabelecer um projeto de desenvolvimento em equilíbrio com a Mãe Terra para realizar o bem-viver, através do fortalecimento dos saberes locais e conhecimentos ancestrais. (BOLIVIA, 2012, p. 3) A lei adota no artigo 4 dezessete princípios para a integração do bem-viver e dos direitos da natureza com o desenvolvimento econômico, a saber: a) compatibilidade e complementariedade de direitos, obrigações e deveres (da Mãe Terra; coletivos e individuais das nações e povos indígenas, interculturais e afrobolivianas; civis, políticos, sociais, econômicos e culturais do povo boliviano; e os da população urbana e rural a viver em uma sociedade justa, equitativa e solidária); b) vedação à mercantilização das funções ambientais da Mãe Terra; c) integralidade (inter-relação, interdependência e funcionalidade dos processos); d) da precaução ou precautório; e) garantia de restauração da Mãe Terra; f) garantia de regeneração da Mãe Terra; g) responsabilidade histórica (dos danos causados à natureza); h) prioridade da prevenção; i) participação plural (mediante procedimentos consensuais e democráticos); j) água para a vida; k) solidariedade entre seres humanos; 1) relação harmônica (dinâmica, adaptativa e equilibrada entre necessidades públicas e capacidade de regeneração da natureza); m) justiça social; n) justiça climática; o) economia plural (permitindo a convivência entre sistemas econômicos distintos) (MELO, 2016); p) complementariedade e equilíbrio (dos seres vivos na Mãe Terra); q) diálogo de saberes (tradicionais e científicos) (BOLIVIA, 2012, p. 4-6).

No plano judicial, no ano de 2011, os estadunidenses Richard Wheeler e Eleanor ("Norie") Huddle, proprietários de terreno na cidade de Vilcabamba, localizada na região de Loja, no interior do Equador, ajuizaram ação de proteção constitucional, com fundamento no segundo parágrafo do art. 71 da Constituição, para responsabilizar o Governo Provincial de Loja por causar danos ao Rio Vilcabamba, decorrentes de enchentes ocasionadas pela disposição antrópica de grandes quantidades de terras e outros materiais em sua margem e leito, oriundos das escavações para construção de uma estrada, sem o devido estudo de impacto ambiental. No caso, o apelo constitucional não buscava indenização pessoal, mas uma ação em representação da natureza (HUDDLE, 2013, p. 17). A ação de proteção, na forma do art. 88 da Constituição, tem como objeto amparar direta e eficazmente os direitos reconhecidos no texto constitucional, podendo ser interposto, entre outras hipóteses, no caso de violação a direitos constitucionais por ação ou omissão de autoridade pública.

Em 30 de março de 2011, em sede recursal, a Corte Provincial de Justiça de Loja deu provimento para a ação. Argumentou-se que, dada a indiscutível importância que possui a natureza, e tendo em conta o seu processo de degradação, a ação de proteção constitucional seria a única via idônea e eficaz para impedir e reparar de maneira imediata um dano ambiental, e que é dever dos 
juízes constitucionais determinar imediatamente a proteção dos direitos da natureza e tornar efetiva a tutela judicial, ainda que com base na probabilidade. Quanto aos direitos da natureza, assevera que o art. 71 da Constituição equatoriana aponta a importância evidente e indiscutível da natureza, cujos danos a ela causados são geracionais, razão pela qual deveria ter sido reconhecida na origem a inversão do ônus da prova, na forma do art. 397 da Constituição, contra o poluidor, ainda que se trate de ente público. Por fim, entende que não haveria que se falar em sopesamento de interesses entre a necessidade das populações da região de uma estrada e a proteção ambiental, pois não haveria colisão de direitos constitucionais, nem sacrifício de um em detrimento do outro, pois o que se põe aqui é a construção da estrada seja feita respeitando os direitos constitucionais da natureza e, assim, o interesse público na estrada resta diminuído em comparação com o direito a um meio ambiente sadio (EQUADOR, 2011, p. 2-5).

É importante destacar que os autores da ação não são nacionais equatorianos, o que ressalta o caráter universal da legitimação extraordinária para a causa. Ademais, trata-se da primeira decisão judicial que promoveu a defesa da personalidade da natureza, o que sugere que a constitucionalização não foi apenas um reflexo de constituição-álibi (NEVES, 2016). Além do mais, foi reconhecida a personalidade de um rio, que corresponde a um ecossistema integrado por elementos orgânicos e inorgânicos. No entanto, grandes obstáculos foram enfrentados para a execução da decisão judicial, tendo no ano seguinte se concluído que não foram cumpridas todas as recomendações da sentença, tendo sido ajuizada uma ação de descumprimento (SUÁREZ, 2013, p. 4-9). Defensores da Jurisprudência da Terra têm incorporado as contribuições políticas e jurídicas oriundas dos direitos da natureza sul-americanos, bem como de outras experiências mundiais, para reforçar seu aporte teórico. (SIEMEN, 2013, online).

Observa-se, portanto, que não se verifica uma inação desses países na promoção dos direitos da natureza. Aliás, a Bolívia vem sendo protagonista em alguns processos internacionais de promoção dos valores associados ao bem-viver e aos direitos da natureza. Um deles foi a proposição da Declaração Universal dos Direitos da Mãe Terra, apresentada na Conferência Mundial dos Povos sobre a Mudança Climática e os Direitos da Mãe Terra, realizada no dia 22 de abril de 2010, em Cochabamba, Bolívia. Tal Declaração aponta como direitos inerentes à Mãe Terra, no artigo 2, os direitos à vida e à existência, a ser respeitada, a regenerar sua biocapacidade e a continuar seus ciclos e processos vitais livres de interrupção humana, a manter sua identidade e integridade como um ser distinto, autorregulador e inter-relacionado; à água como fonte de vida, ao ar limpo, à saúde integral, à liberdade face a contaminação, poluição e lixo tóxico ou radioativo, a incolumidade de sua estrutura genética de modo a ameaçar sua integridade ou funcionamento vital e saudável, e à completa e imediata restauração por violação aos direitos causada por ação antrópica (WORLD..., 2010, online).

No âmbito das Nações Unidas, em 2009, foi adotada pela Assembleia Geral resolução que designa o dia 22 de abril como Dia Internacional da Mãe Terra (UNITED NATIONS, 2009a). Posteriormente, a Bolívia apresentou a resolução que culminou com a declaração do direito humano à água potável e ao saneamento básico, em julho de 2010 (UNITED NATIONS, 2010). Acosta (2010d) sugere que o Equador poderia ocupar uma posição de liderança em iniciativas dessa natureza, ao lado da Bolívia e que, assim como a Declaração Universal dos Direitos Humanos, de 1948, exigiu e ainda demanda esforço permanente, deve ser empreendido um esforço político no contexto diplomático, indicando como um interessante caminho para tanto a atuação no Conselho de Direitos Humanos das Nações Unidas.

Em arremate, esse movimento jurídico-político que reconhece personalidade à natureza ao refletir o pensamento autóctone dos povos tradicionais das nações andinas, pode representar o entendimento jurídico generalizado, não apenas na América do Sul, mas de todo o hemisfério sul. 
É possível verificar isso a partir de recentes decisões em torno da mesma tese. Em 2014, foram finalizadas as tratativas para a aprovação de um novo regime jurídico para o rio Whanganui, na Nova Zelândia. Após um acordo com o governo nacional e a comunidade tradicional local Whanganui Iwi, uma das tribos nativas maori da região, a Te Awa Tupua Bill (Whanganui River Claims Settlement) estabelece esse novo regime jurídico, denominado Te Pā Auroa, cujo elemento central consiste no reconhecimento do Te Аwa Тириа - o complexo consistente no rio desde sua nascente até sua foz, os rios tributários e todos os elementos físicos e metafísicos inerentes (art. 12) - como um todo vivo e indivisível, dotado de personalidade jurídica, com direitos, poderes, deveres e responsabilidades (art. 14) (NEW ZEALAND, 2016, online).

Em 2016, a Corte Constitucional da Colômbia, numa ação de tutela apresentada contra a Presidência da República colombiana em razão da poluição no rio Atrato, o mais caudaloso da região, causada principalmente pela atividade minerária, conferiu ao rio e à bacia a que pertence o status de entidade sujeito de direitos à proteção, conservação, manutenção e restauração face ao Estado e às comunidades étnicas lá localizadas (COLOMBIA, 2016, p. 158).

Mais recentemente, em março de 2017, a Corte Superior de Uttarakhand, um dos estadosmembros da Índia, localizado na região central e que faz fronteira com a China e o Nepal, também proferiu decisões judiciais em conformidade com os direitos da natureza. Inicialmente, conferiu aos rios Ganges e Yamuna e seus afluentes e quaisquer correntes d'água a eles relacionados, com base no reconhecimento e na fé da sociedade indiana e na importância imemorial desses rios na saúde, inclusive espiritual, e bem-viver dos povos indianos, a natureza de "juristic / legal persons / living entities", em outras palavras, o status de pessoa jurídica, com direitos, deveres e responsabilidades (INDIA, 2017a). No final do mesmo mês, foi a vez de ampliar a condição de pessoa jurídica de maneira mais radical, abrangendo desde as montanhas do Himalaia, as geleiras, nascentes, rios, córregos e riachos, até a selva, florestas, prados e pântanos, bem como o próprio ar (INDIA, 2017b).

Há, portanto, um contraste entre a ação do pensamento racionalista ocidental da Jurisprudência da Terra, que se restringe ao pensamento teórico-científico, e a prática dos atores do sul, ligados ao pensamento emancipador dos povos tradicionais. No entanto, as práticas do hemisfério sul, aliadas aos valores tradicionais, foram manifestações com verdadeira força normativa - tanto assim que deram respaldo a decisões judiciais que reconheceram tais práticas e valores, com efeito similar aos costumes jurídicos, embora sem expressarem dessa maneira. Ainda que se considerem a Nova Zelândia e a Índia como países que compartilham da tradição anglófona, as experiências práticas de reconhecimento dos direitos da natureza partem dos valores dos povos tradicionais. Todavia, conquanto sejam atitudes contrapostas, buscam um denominador comum e é com essa visão que se busca uma iniciativa global integrada.

\section{A HARMONIA COM A NATUREZA (HARMONY WITH NATURE) NO CONTEXTO INTERNACIONAL: UMA TENDÊNCIA PARA MUDANÇAS NO PARADIGMA AMBIENTAL GLOBAL}

Enquanto a Jurisprudência da Terra configura-se como uma corrente doutrinária de matriz anglófona, e os direitos da natureza como uma categoria política de raízes latino-americanas, a Harmonia com a Natureza emerge como um programa conduzido pelas Nações Unidas, como forma de articular as duas tendências, entre outras experiências mundiais. Nesta seção, propõe-se um exame histórico da evolução desse programa, a partir da análise das resoluções anuais da Assembleia Geral. 
Uma menção à harmonia com a natureza remonta aos anos 1980, com a Resolução 35/7, que trata do rascunho da Carta Mundial da Natureza. Nos considerandos do documento, a Assembleia Geral reafirma que a humanidade pode e deve existir em harmonia com a natureza, exercitando administração sobre ela no interesse da presente e das futuras gerações (UNITED NATIONS, 1980). Na Carta, aprovada pela Resolução 37/7, em anexo, novamente nos considerandos, proclama-se que a Assembleia Geral da ONU está ciente de que a civilização deita raízes na natureza e que viver em harmonia com a natureza proporciona à humanidade as melhores oportunidades para o desenvolvimento da criatividade e para o descanso e recreação (UNITED NATIONS, 1982). A Declaração do Rio de 1992 traz no seu primeiro princípio o direito à vida saudável e produtiva em harmonia com a natureza.

O programa Harmonia com a Natureza somente tem seus primeiros passos em 2009. A Resolução 64/196 da Assembleia Geral das Nações Unidas, levando em conta a Carta Mundial da Natureza (1982), a Declaração do Rio sobre Meio Ambiente e Desenvolvimento (1992), a Agenda 21, a Declaração de Johanesburgo sobre Desenvolvimento Sustentável (2002), a Cúpula Mundial de 2005 e o Dia Internacional da Mãe Terra, diante da preocupação com a degradação ambiental e convencida da possibilidade de viver em harmonia com a natureza, convida os Estados membros, as organizações do sistema onusiano e outras organizações internacionais, regionais e subregionais a considerar o tema da harmonia com a natureza e transmitir visões, experiências e propostas. Ademais, decide incluir, na agenda da próxima sessão, um subitem intitulado "Harmonia com a Natureza" sob o gênero "Desenvolvimento sustentável” (UNITED NATIONS, 2009b).

No ano seguinte, a Resolução 65/164 aponta uma abordagem mais ampla do problema. Nos considerandos, inclui ainda os Dias Mundiais da Água (22 de março), da Preservação da Camada de Ozônio (19 de dezembro) e da Diversidade Biológica (22 de maio) e o ano de 2011 como o Ano Internacional das Florestas, menciona a Conferência Mundial dos Povos sobre Mudanças Climáticas e os Direitos da Mãe Terra, ocorrido em abril de 2010. Mais especialmente, a Assembleia Geral reconhece que muitas civilizações antigas e culturas indígenas possuem uma rica história de conexão simbiótica com a natureza que fomenta uma relação mutualmente benéfica e considera que a noção de desenvolvimento sustentável é um conceito holístico que requer o fortalecimento de conexões interdisciplinares em diferentes áreas do conhecimento. No conteúdo da resolução, as Assembleia Geral toma nota do primeiro relatório sobre o tema e requisita ao Secretário-Geral a realização de um diálogo interativo durante a comemoração do Dia Internacional da Mãe Terra, com a participação de todos os atores internacionais interessados, para contribuírem ativa e efetivamente e apoiar esforços no processo preparatório da Conferência Rio+20, a respeito de formas de promover uma abordagem holística para o desenvolvimento sustentável em harmonia com a natureza e de difusão de experiências nacionais de critérios e indicadores de mensuração do desenvolvimento sustentável (UNITED NATIONS, 2010b).

Em 2011, a Resolução 66/204, reiterando as disposições da resolução anterior, acrescenta que a Assembleia Geral reafirma que mudanças fundamentais na forma como as sociedades produzem e consomem é indispensável para alcançar o desenvolvimento sustentável global e que todos os países devem promover padrões de consumo e produção sustentáveis, com a liderança dos países desenvolvidos e beneficiando a todos os países, com base no princípio das responsabilidades comuns porém diferenciadas (UNITED NATIONS, 2011b).

No ano de 2012 ocorreu a Rio+20, a Conferência do Rio sobre Desenvolvimento Sustentável, no qual foi aprovada a Resolução 66/288, denominada O futuro que queremos. No item II, quanto à renovação dos compromissos políticos, a Assembleia Geral das Nações Unidas reconhece que o planeta Terra e seus ecossistemas são nossa casa e que "Mãe Terra" é uma expressão comum a número de países e regiões, e que alguns países reconhecem os direitos da 
natureza no contexto da promoção do desenvolvimento sustentável, e está convencida de que é necessário promover a harmonia com a natureza para alcançar o equilíbrio entre as necessidades econômicas, sociais e ambientais intergeracional (item 39). Em seguida, convoca por abordagens holísticas e integradas para a harmonia com a natureza (item 40) (UNITED NATIONS, 2012a).

No mesmo ano, a Resolução 67/214 determinou que o diálogo interativo anual de 2013 progredisse nas discussões sobre abordagens econômicas, no contexto do desenvolvimento sustentável, para direcionar uma base mais ética para a relação entre a humanidade e a Terra. Ademais, dá boas-vindas ao lançamento do portal Harmonia da Natureza (http:// www.harmonywithnatureun.org/), bem como incorpora as contribuições da Rio+20 acima assinaladas. (UNITED NATIONS, 2012b).

Em 2013, a Resolução 68/216 acrescenta que a Assembleia Geral reconhece que um número significativo de países considera a Mãe Terra como a fonte de toda a vida e sustento, e a Mãe Terra e a humanidade como uma comunidade viva e indivisível de seres inter-relacionados e interdependentes. No mérito, convida os Estados a construir uma rede de conhecimento para promover uma concepção holística para identificar diferentes abordagens econômicas que refletem os condutores e valores da vida em harmonia com a natureza e, o que importa ressaltar, a promover harmonia com a Terra, como encontrado em culturas indígenas, e a prover apoio e promover os esforços feitos do nível nacional ao comunitário para refletir a proteção da natureza (UNITED NATIONS, 2013a).

A Resolução 69/224, tomada em 2014, praticamente pouco inovou, mantendo a continuidade do programa (UNITED NATIONS, 2014a). Em 2015, ocorreu a Cúpula das Nações Unidas sobre Desenvolvimento Sustentável, cuja Resolução 70/1, intitulada Transformando nosso mundo: a Agenda 2030 para o Desenvolvimento Sustentável, previu, entre as dimensões aplicáveis para os objetivos e metas do desenvolvimento sustentável, a prosperidade, assim entendido o compromisso de assegurar que todos os seres humanos possam gozar de vidas prósperas e plenas e que o progresso econômico, social e tecnológico ocorra em harmonia com a natureza. $\mathrm{O}$ documento ainda apresenta uma visão de um mundo no qual a humanidade viva em harmonia com a natureza e no qual a vida selvagem e outras espécies vivas são protegidas. E no objetivo 12 assegurar padrões de consumo e produção sustentáveis - , uma das metas é, até 2030, assegurar que as pessoas tenham informação relevante e consciência para o desenvolvimento sustentável e estilos de vida em harmonia com a natureza (UNITED NATIONS, 2015a).

No mesmo ano, a Resolução 70/208 decide iniciar, em 2016, um diálogo virtual sobre Harmonia com a Natureza com pesquisadores da Jurisprudência da Terra, de modo a inspirar cidadãos e sociedades a reconsiderar como eles interagem com o mundo natural para implementar os objetivos do desenvolvimento sustentável em harmonia com a natureza (UNITED NATIONS, 2015b). A Resolução 71/232, da sessão de 2016, ressalta o relatório resumido do primeiro diálogo virtual da Assembleia Geral sobre Harmonia com a Natureza com pesquisadores da Jurisprudência da Terra, bem como convida os Estados a considerar os estudos existentes e as descobertas e recomendações dos relatórios do Secretário-Geral acerca da Harmonia com a Natureza, na promoção da integração equilibrada das dimensões econômica, social e ambiental do desenvolvimento sustentável através da harmonia com a natureza (UNITED NATIONS, 2016a). Por fim, em 2017, o rascunho da próxima resolução reitera os mesmos pontos, mas acrescenta um alerta às Nações Unidas para intensificar o apoio aos países na implementação plena da Nova Agenda Urbana adotada no Habitat III, considerando uma visão das cidades como espaços para proteção, conservação, recuperação e promoção de seus ecossistemas e biodiversidades, com enfoque na sustentabilidade dos padrões de consumo e produção (UNITED NATIONS, 2017a). 
Em cada Resolução anual concernente à Harmonia com a Natureza, constava uma determinação ao Secretário-Geral da ONU para realizar um diálogo interativo sobre Harmonia com a Natureza, realizada sempre no Dia Mundial da Mãe Terra do ano seguinte, e para elaborar um relatório acerca da implementação da própria Resolução, inclusive com base nas discussões levantadas nesses diálogos anuais. Os quatro primeiros relatórios preocuparam-se em diagnosticar a situação de crise ambiental e mudanças climáticas e, quanto ao conteúdo proposto, apresentaram uma abordagem metodológica mista, intercalando pesquisa histórica, das relações homem-natureza desde os primórdios da civilização humana, e pesquisa comparada, ou seja, como os países hoje estão lidando com essa relação homem-natureza, com exame de casos. Foram relatórios ainda bastante incipientes e descritivos, com pouco aprofundamento sobre o que se deveria entender por harmonia com a natureza. No primeiro deles, há uma tendência para a adoção da filosofia do holismo (UNITED NATIONS, 2010c, item 102); no segundo, há uma convocação para uma mudança de paradigma econômico, não mais baseado no PIB, e de valores, que promova o bemestar guiado pela natureza (UNITED NATIONS, 2011c, itens 65, 77 e 79); no terceiro relatório, introduz-se o conceito de antropoceno, aponta-se para a relação integral entre homem e natureza, reitera-se a necessidade de mudança de paradigmas, bem como acena-se no sentido de que a nova abordagem econômica deve ser feita a partir de um conceito de valor subjacente à preservação e proteção da saúde dos ecossistemas (UNITED NATIONS, 2012c, itens 34 e 59). No relatório de 2013, estipula-se que a harmonia com a natureza conclama para a reabilitação do espírito humano, para o conceito de holismo e para a busca de um estilo de vida que respeita os direitos da natureza (UNITED NATIONS, 2013b, item 61).

A partir do relatório de 2014 é possível observar uma mudança qualitativa na abordagem utilizada, demonstrando grandes avanços para o que se deve considerar como harmonia com a natureza. Sem prejuízo de agregar contribuições de outros ramos da ciência, principalmente das exatas, foram incorporadas em várias passagens as reflexões desenvolvidas a partir do bem-viver, da relação telúrica estabelecida entre as sociedades humanas e a natureza, dos direitos de Pachamama, bem como o aporte teórico-jurídico da Jurisprudência da Terra e dos direitos da natureza, sob o viés ecocêntrico. Foram também relatadas experiências judiciais em que se reconheceram direitos a rios. O relatório passa a agregar, no léxico dos diálogos, o conceito de governança do sistema da Terra, como uma proposta de governança econômico-ambiental global, e a concepção de prosperidade, como nova abordagem em substituição à noção de crescimento (UNITED NATIONS, 2014b, itens 5, 11, 15 e 16, 21 a 24, 58-66).

O relatório de 2015 dedica especial consideração para os conhecimentos tradicionais e indígenas como um caminho produtivo para o aprimoramento da pesquisa em harmonia com a natureza, em virtude de funcionarem sobre um parâmetro holístico. A noção de reciprocidade é introduzida no discurso, como um dos princípios fundamentais do direito costumeiro, e que os direitos da natureza expressam esse movimento, e a Jurisprudência da Terra fomentaria a teoria de base. (UNITED NATIONS, 2015c, itens 13-17, 23-30, 40-41, 46-47). O relatório do ano seguinte, em atenção à determinação dada na Resolução 70/208, configura-se como um manifesto dos pesquisadores da Jurisprudência da Terra com o propósito de aprofundar os conhecimentos sobre essa doutrina e as formas de implementação prática em diversas perspectivas - jurídica, econômica, pedagógica, filosófica, ética e artística. Sob o aspecto jurídico, recomenda-se a inclusão dos direitos da natureza como forma de reconhecer os direitos fundamentais dos ecossistemas e espécies para existir, prosperar e regenerar-se, e a imposição de obrigações aos seres humanos de respeitar as funções e os direitos de membros não humanos da comunidade da Terra. $\mathrm{O}$ reconhecimento dos direitos da natureza, contudo, não são suficientes, pois restam os obstáculos 
de garantir a exigibilidade e eficácia desses direitos através de uma modificação ou eliminação dos direitos das empresas (UNITED NATIONS, 2016b).

O relatório mais recente, datado de julho de 2017, também contemplando uma síntese do diálogo interativo sobre Harmonia com a Natureza ocorrido em abril do mesmo ano, discorre sobre iniciativas dos expertos para a instituição de um conselho tutelar da Terra, composto por todos os países, para o desenvolvimento de uma economia para a Terra galgada no aprimoramento mútuo entre homem e natureza e na justiça intergeracional, e para a necessidade de implementação da Agenda 2030 para o Desenvolvimento Sustentável feita com respeito aos princípios da Harmonia com a Natureza. Além disso, faz-se um relato geral sobre as experiências colombiana, neozelandesa e indiana já mencionadas na seção anterior, acrescendo a introdução de direitos da natureza na Constituição da Cidade do México de 2017 e de iniciativas semelhantes nos Estados Unidos, na União Europeia e na África relativas à apreciação de direitos da natureza. Num terceiro momento, dedica atenção à necessidade de que a educação também seja empreendida a partir da visão da Harmonia com a Natureza. Ao final, o relatório conclui pelo crescimento da convergência mundial em prol de uma relação holística com a natureza (UNITED NATIONS, 2017b, itens 16, 18, 20 , 28-54, 91).

De forma crítica, percebe-se que a Harmonia com a Natureza se encontra fortemente atrelada ao arcabouço teórico do desenvolvimento sustentável, o que pode se demonstrar incompatível com a proposta que se busca alcançar. Uma mudança de paradigma implica também uma mudança da forma de pensar. Observa-se, por outro lado, uma mudança no discurso, ao longo das resoluções da ONU, ao implementar cada vez mais um modelo ecocêntrico, tal como defendido pela Jurisprudência da Terra e pelos direitos da natureza. Para tanto, vem se desenvolvendo um novo léxico capaz de dar conta dessa mudança, a exemplo da prosperidade, reciprocidade e integração equilibrada das dimensões da vida.

A crescente inserção do tema no cenário internacional vem produzindo repercussão em outros importantes atores do cenário internacional, como aconteceu com a Santa Sé, com a Encíclica Laudato Si', de 2015. Trata-se da primeira encíclica papal que tem como principal preocupação a questão da sustentabilidade da vida humana no planeta. Há um forte apelo da Jurisprudência da Terra quando o Papa Francisco propõe o "desafio de proteger a nossa casa [...] na busca de um desenvolvimento sustentável e integral" mediante uma reflexão do que denomina de ecologia integral, "inseparável da noção de bem comum", e sugere que "reduzir um determinado ritmo de produção e consumo pode dar lugar a outra modalidade de progresso e desenvolvimento", para "proporcionar outros benefícios econômicos a médio prazo" (SANTA SÉ, 2015).

\section{CONSIDERAÇÕES FINAIS}

Com base no que foi exposto e desenvolvido ao longo desta investigação, sem prejuízo do reconhecimento do caráter simplificador, pode-se esboçar as diferenças entre as propostas conforme a Tabela 1. 
Tabela 1 - Comparação entre as duas matrizes jurídicas ecocêntricas Jurisprudência da direitos da natureza (derechos de la Terra (Earth Jurisprudence) naturaleza)

\begin{tabular}{|c|c|c|c|}
\hline & Matriz & Anglo-saxônica & Latino-americana \\
\hline & Origem & Doutrinária & Costumeira \\
\hline & Visão & $\begin{array}{l}\text { Científico-racional e } \\
\text { poético-imagético }\end{array}$ & $\begin{array}{l}\text { Povos autóctones } \\
\text { originários tradicionais }\end{array}$ \\
\hline (2) & Base & Dignidade da natureza & Bem-viver \\
\hline & Concepção & $\begin{array}{l}\text { Terra como ser vivo, } \\
\text { da qual somos parte } \\
\text { integrante }\end{array}$ & $\begin{array}{l}\text { Mãe Terra como uma } \\
\text { divindade, } \\
\text { da qual todos são filhos }\end{array}$ \\
\hline & Compreensão & 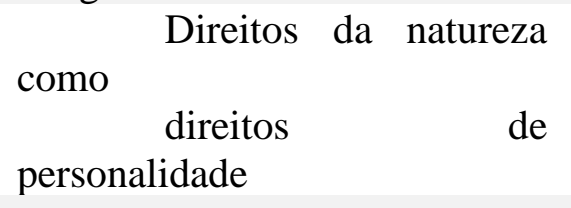 & $\begin{array}{l}\text { Direitos da natureza } \\
\text { como direitos de Pachamama ou } \\
\text { da Mãe Terra }\end{array}$ \\
\hline & Finalidade & Florescimento & Harmonia \\
\hline & Filosofia & $\begin{array}{l}\text { Ecologia jurídica } \\
\text { profunda }\end{array}$ & $\begin{array}{l}\text { Ecologismo } \\
\text { constitucional }\end{array}$ \\
\hline jurídica & Positivação & $\begin{array}{c}\text { Pesquisa } \\
\text { interpretação de normas } \\
\text { (soft law) }\end{array}$ & $\begin{array}{l}\text { Constituições, leis e } \\
\text { jurisprudência } \\
\text { (hard law) }\end{array}$ \\
\hline
\end{tabular}

Fonte: elaboração própria.

Ainda em relação à contraposição entre esses dois movimentos, pode-se destacar duas vantagens em favor dos direitos da natureza latino-americanos. De um lado, essa corrente tem bases que remontam a costumes tradicionais de priscas eras dos povos originários, podendo, dessa forma, ser considerada a mais antiga entre elas. A positivação nas Constituições sul-americanas, embora num marco cronológico recente, não significa que somente agora essa concepção exista, mas retrata o reconhecimento e a elevação do status jurídico dessa prática reiterada (inveterata consuetudo) com sentimento de força normativa vinculante (opinio juris vel necessitatis). Embora seja possível afirmar que a tematização desse problema oriundo da cosmovisão indígena, com o desenvolvimento de investigações, somente tenha alçado ares jurídicos a partir dessa constitucionalização, não significa que tal costume já não estivesse devidamente estabelecido. De outro lado, originada de um processo de formação jurídica difusa, com forte teor político, sua implicação nos dias de hoje se faz muito mais presente, com maior permeabilidade nas várias instâncias políticas, como se percebe pelos atos normativos aprovados e decisões judiciais tomadas.

Nada obstante, à Jurisprudência da Terra deve-se reconhecer suas próprias conquistas. Uma delas é desenvolver uma teoria jurídica de matriz ecocêntrica no idioma oficial do planeta, permitindo maior repercussão desse conhecimento, bem como a difusão das experiências alcançadas com os derechos de la naturaleza, e a multiplicação das investigações nessa área em diversos países que não adotam os dialetos espanhóis. Contudo, a principal conquista dessa corrente é, sem dúvidas, a construção de uma base teórica a partir da concepção filosófica e epistemológica no seio da tradição moderna antropocêntrica, com suporte no pensamento racional 
e nas investigações em imaginário jurídico e por meio do desenvolvimento de conceitos tradicionais na Filosofia prática (dignidade) e na Ciência do Direito (direitos da personalidade). Tal missão é de importância ímpar, haja vista que faz uma tradução da cosmovisão dos povos tradicionais originários para o discurso civilizatório, abrindo margem a um diálogo saudável entre diferentes culturas.

Em conclusão, a iniciativa Harmonia com a Natureza tem grandes méritos, inerentes à missão de sistematizar o conhecimento em torno de uma nova forma de lidar com o meio ambiente. Um dos méritos foi realizar a aproximação entre uma corrente científica do Direito — a Jurisprudência da Terra — com uma manifestação política da nova realidade que se apresenta os direitos da natureza —, oriundas de regiões distintas do mundo, demonstrando assim um potencial agregador de interesses diferentes em prol de uma causa comum. O diálogo entre essas manifestações jurídicas vem causando uma apropriação recíproca dos resultados positivos de cada um.

Outro mérito encontra-se na aproximação dessas experiências regionais - a Jurisprudência da Terra de matriz anglófona e os direitos da natureza na América do Sul — com experiências equivalentes em outras partes no mundo. Exemplificativamente, cabe mencionar aqui a Resolução 64/253, de 2010, que, com o propósito de reconhecer o dia 21 de março como o Dia Internacional do Nowruz, coloca em evidência esse evento, próprio dos países localizados mormente nos Balcãs, na bacia do Mar Negro, no Cáucaso, na Ásia Central e no Oriente Médio, relacionado com o equinócio da primavera e comemorado através de tradições e rituais ancestrais, cuja orientação se dá em direção à vida em harmonia com a natureza e a consciência do vínculo inseparável entre o trabalho construtivo e os ciclos naturais de renovação e de uma atitude solícita e respeitosa perante as fontes naturais de vida (UNITED NATIONS, 2010a). Além desse, há de se destacar também o tema da felicidade, capitaneado pelo Butão, que propõe um novo indicador de bem-estar, de desenvolvimento ou de prosperidade, denominado de Felicidade Interna Bruta (UNITED NATIONS, 2011b).

Um terceiro mérito pode ser observado nas próprias resoluções da ONU. Os documentos mais importantes dos últimos anos relacionados ao tema da proteção ambiental - Declaração do Rio de 1992, a Declaração da Rio+20 (O Futuro que Queremos) e os Objetivos para o Desenvolvimento Sustentável 2030 - estão incorporando a questão da harmonia com a natureza, mencionando o enfoque ecocêntrico, através do reconhecimento dos direitos da natureza, como um caminho cada vez mais possível de ser trilhado no cenário internacional e, assim, com repercussões nacionais. Há, nesse ponto específico, a percepção de uma caminhada lenta e gradual do Direito Ambiental em direção a uma proposta ecocêntrica de relação com a natureza. Tratando-se de perspectivas que lidam com paradigmas distintos, pode-se cogitar de um conflito iminente entre jus-ambientalistas e jus-ecocentristas. Nada obstante, consideram-se mais apropriadas as visões que buscam a harmonização entre os pontos de vista:

Vale dizer, mesmo que, no contexto da geração atual, não valorizemos adequada e suficientemente o meio ambiente ou seus elementos (como algo que ultrapasse a noção de res), ainda assim haveríamos de protegê-los, porque as gerações futuras podem vir a estimá-lo de modo diverso do nosso (= menos antropocentricamente), inclusive conferindo-lhes a posição de sujeito de direitos. Por esse enfoque, o papel do Direito Ambiental seria o de assegurar às gerações futuras a opção de poder reorganizar (ou redimensionar) seu sistema ético-jurídico, retificando a coisificação da natureza, o que seria impossível ou inútil sem a conservação, pelas gerações anteriores, da própria natureza e de seus atributos preponderantes. (BENJAMIN, 2011, p. 87)

Embora o debate travado nesta investigação pareça um tanto distante da realidade brasileira, no contexto de globalização, de integração dos ordenamentos jurídicos nos sistemas 
internacionais de proteção de direitos humanos, como também do transconstitucionalismo, a sinalização do cenário internacional para um novo paradigma de proteção de direitos implica, no âmbito interno, possíveis mudanças na interpretação das normas constitucionais. A presente pesquisa aponta para um caminho que se apresenta nesse cenário internacional das Nações Unidas, a saber, o do ecocentrismo pela harmonia com a natureza, galgado tanto numa experiência constitucional latino-americana quanto no respaldo teórico de matriz anglo-saxã. Nesse sentido, a evidente e crescente ascensão dos direitos da natureza teria o condão de superar interpretações antropocêntricas das normas constitucionais de Direito Ambiental em ações judiciais, como foi discutido anteriormente, em relação a experiências de cortes estrangeiras (Equador, Colômbia e Índia). Revelar essa nova matriz de proteção de direitos fundamentais, da natureza, está, portanto, diretamente ligada à ideia de justiça constitucional.

Em virtude disso, deve-se examinar de perto a recente ação judicial impetrada pelo Rio Doce no Poder Judiciário de Belo Horizonte, representada por associação civil sem fins lucrativos, face às omissões dos poderes públicos em conduzir adequadamente os processos de indenização e reparação dos danos causados pela tragédia em Mariana. Trata-se da primeira ação judicial brasileira na qual um rio pede o reconhecimento judicial de sua condição de sujeito de direitos (ONG PACHAMAMA, 2017, online). A adoção das teorias clássicas de responsabilidade civil em situações como a do colapso ambiental do Rio Doce - nos quais a determinação dos danos é dotada de uma complexidade própria - , como a aplicação da teoria do risco integral no Direito Ambiental, pode ocasionar "uma situação de vazio responsabilizador" (BELCHIOR; PRIMO, 2016, p. 27). Nesse sentido, a convergência global para uma nova percepção da relação jurídica entre homem e natureza, com reflexos no Brasil, poderia desencadear a necessária evolução da responsabilidade ambiental do ponto de vista pretoriano e até mesmo legislativo.

\section{REFERÊNCIAS}

ACOSTA, Alberto. El buen vivir en el camino del post-desarrollo: una lectura desde la Constitución de Montecristi. Policy Paper 9, oct. 2010. Quito: Friedrich Ebert Stiftung, 2010 b.

ACOSTA, Alberto. O buen vivir: uma oportunidade de imaginar um outro mundo. In: BARTELT, Dawid Danilo (ed.). Um campeão visto de perto: uma análise do modelo de desenvolvimento brasileiro. Rio de Janeiro: Heinrich Böll Stiftung, 2012, p. 198-216. (Série Democracia). Disponível em: <https://br.boell.org/sites/default/files/democracia_inside_a_ champion_port_final.pdf>. Acesso em: 7 jul. 2017.

ACOSTA, Alberto. Toward the universal declaration of rights of nature: thoughts for action. AFESE journal, 24 aug. 2010. Disponível em: <http://therightsofnature.org/wp-content/uploads/ pdfs/Toward-the-Universal-Declaration-of-Rights-of-Nature-Alberto-Acosta.pdf $>$. Acesso em: 8 jul. 2017.

BARRY, Thomas. The spirituality of the Earth. In: BIRCH, Charles; EAKEN, William; MCDANIEL, Jay B. (eds.). Liberating life: contemporary approaches in ecological theology. Ossining: Orbis, 1990, p. 151-158.

BELCHIOR, Germana Parente Neiva; PRIMO, Diego de Alencar Salazar. A responsabilidade civil por dano ambiental e o caso Samarco: desafios à luz do paradigma da sociedade de risco e 
da complexidade ambiental. Revista Jurídica da UNI7, Fortaleza, v. 13, n. 1, p. 10-30, jan./jun. 2016. Disponível em: <http://www.uni7setembro.edu.br/periodicos/index.php/revistajuridica/ article/view/38>. Acesso em: 14 nov. 2017.

BENJAMIN, Antonio Herman de Vasconcellos e. A natureza no direito brasileiro: coisa, sujeito ou nada disso. Nomos: Revista do Programa de Pós-Graduação em Direito da UFC, Fortaleza, v. 31, n. 1, p. 79-96, jan./jun. 2011. Disponível em: <http://www.periodicos.ufc.br/nomos/article/ view/398/380>. Acesso em: 14 nov. 2017.

BOLIVIA. Constituição (2009). Nueva Constitución Política del Estado. La Paz: Asamblea Constituyente de Bolivia, 2008. Disponível em: <http://www.comunicacion.gob.bo/sites/default/ files/docs/Nueva_Constitucion_Politica_del_Estado_Boliviano_0.pdf >. Acesso em: 7 jul. 2017.

BOLIVIA. Constituição (2009). Ley no 300: ley de 15 de octubre de 2012. Ley Marco de la Madre Tierra y Desarrollo Integral para Vivir Bien. Gaceta Oficial del Estado Plurinacional de Bolivia, La Paz, n. 431, p. 3-44, 15 oct. 2012. Disponível em: <http:// www.harmonywithnatureun.org/>. Acesso em: 8 jul. 2017.

BOSSELMANN, Klaus. Eigene Rechte für die Natur? Ansätze einer ökologischen Rechtsauffassung. Kritische Justiz, ano 19, n. 1, p. 1-22, 1986. Disponível em: <https:// www.nomos-elibrary.de/10.5771/0023-4834-1986-1-1/eigene-rechte-fuer-die-natur-ansaetzeeiner-oekologischen-rechtsauffassung-jahrgang-19-1986-heft-1>. Acesso em: 3 nov. 2017.

BOSSELMANN, Klaus. Wendezeit im Umweltrecht. Von der Verrechtlichung der Ökologie zur Ökologisierung des Rechts (Teil I). Kritische Justiz, ano 18, n. 4, p. 345-361, 1985. Disponível em: <https://www.nomos-elibrary.de/10.5771/0023-4834-1985-4-345/wendezeit-imumweltrecht-von-der-verrechtlichung-der-oekologie-zur-oekologisierung-des-rechts-teil-ijahrgang-18-1985-heft-4?hitid=2\&search-click>. Acesso em: 3 nov. 2017.

BRANDÃO, Pedro. O novo constitucionalismo pluralista latino-americano. Rio de Janeiro: Lumen Juris, 2015.

BURDON, Peter D. A theory of earth jurisprudence. Australian Journal of Legal Philosophy, v. 37, p. 28-60, 2012. Disponível em: <http://www.austlii.edu.au/au/journals/AUJlLegPhil/>. Acesso em: 6 jul. 2017.

BURDON, Peter D. Wild law: the philosophy of earth jurisprudence. Alternative Law Journal, v. 35, n. 2, 2010. Disponível em: <http://papers.ssrn.com/>. Acesso em: 6 jul. 2017.

COLOMBIA. Corte Constitucional. Sala Sexta de Revisión. T-622 de 2016. Magistrado Ponente Jorge Iván Palacio Palacio, juzgado en 10 nov. 2016. Disponível em: <http:// www.corteconstitucional.gov.co/relatoria/2016/T-622-16.htm>. Acesso em: 6 jul. 2017.

CULLINAN, Cormac. Wild law: a manifesto for earth justice. $2^{\text {nd }}$ ed. Vermont: Chealsea Green, 2011. 
ECUADOR. Constituição (2008). Constitución de la República del Ecuador. Quito: Asamblea Constituyente, 2008. Disponível em: <http://www.asambleanacional.gov.ec/documentos/ constitucion_de_bolsillo.pdf $>$. Acesso em: 7 jul. 2017.

ECUADOR. Constituição (2008). Corte Provincial de Justicia de Loja. Sala Penal. Juicio No: 11121-2011-0010, Casillero No: 826, Juez Ponente Luis Sempértegui Valdivieso, juzgado en: 30 mar. 2011. Disponível em: <https://mariomelo.files.wordpress.com/2011/04/proteccionderechosnatura-loja-11.pdf>. Acesso em: 8 jul. 2017.

ECUADOR. Constituição (2008). Secretaría Nacional de Planificación y Desarrollo. Plan Nacional para el Buen Vivir 2009-2013: construyendo un estado plurinacional e intercultural. Versión resumida. Quito: SENPLADES, 2009. Disponível em: <http:// www.planificacion.gob.ec/wp-content/uploads/downloads/2012/07/Plan_Nacional_para_el_ Buen_Vivir_(version_resumida_en_espanol).pdf>. Acesso em: 8 jul. 2017.

GUDYNAS, Eduardo. La ecología política del giro biocéntrico en la nueva Constitución de Ecuador. Revista de Estudios Sociales, Bogotá, n. 32, p. 34-47, abr. 2009. Disponível em: <http:// www.redalyc.org/pdf/815/81511766003.pdf>. Acesso em: 7 jul. 2017.

GUDYNAS, Eduardo. Los derechos de la naturaleza en serio: respuestas y aportes desde la ecología política. In: GUDYNAS, Eduardo; MARTÍNEZ, Esperanza (comp.). La naturaleza con derechos: de la filosofía a la política. Ecuador: Abya Yala; Universidad Politécnica Salesiana, 2011, p. 239-286. Disponível em: <http://rosalux.org.ec/attachments/article/254/derechosnaturaleza.pdf $>$. Acesso em: 7 jul. 2017.

HOUTART, François. El concepto de Sumak Kausay (Buen vivir) y su correspondencia con el bien común de la humanidad. Ecuador Debate, Quito, n. 84, p. 57-76, dic. 2011. Disponível em: <http://repositorio.flacsoandes.edu.ec/bitstream/10469/3523/1/RFLACSO-ED84-04Houtart.pdf>. Acesso em: 8 jul. 2017.

HUANACUNI MAMANI, Fernando. Buen vivir / vivir bien: filosofía, políticas, estrategias y experiencias regionales andinas. Lima: Coordinadora Andina de Organizaciones Indígenas, 2010. Disponível em: <http://www.economiasolidaria.org/files/1._Consultoria_Vivir_Bien.-InformeFinal.pdf $>$. Acesso em: 7 jul. 2017.

HUDDLE, Norie. World's first successful 'rights of nature' lawsuit. Kosmos: the journal for global citizens creating the new civilization, Lenox, v. 13, n. 1, p. 15-19, fall/winter 2013. Disponível em: <http://www.kosmosjournal.org/>. Acesso em: 8 jul. 2017.

INDIA. High Court of Uttarakhand at Nainital. Writ Petition (PIL) No. 126 of 2014. Mohd. Salim versus State of Uttarakhand \& others. Dated 20 mar. 2017. Disponível em: <http:// lobis.nic.in/>. Acesso em: 8 jul. 2017.

. Writ Petition (PIL) No. 140 of 2015. Lalit Miglani versus State of Uttarakhand \& others. Dated 30 mar. 2017. Disponível em: <http://lobis.nic.in/>. Acesso em: 8 jul. 2017. 
KOONS, Judith E. Earth jurisprudence: the moral value of nature. Pace Environmental Law Review, v. 25, p. 263-339, Summer, 2008. Disponível em: 〈http://papers.ssrn.com/>. Acesso em: 6 jul. 2017.

KOONS, Judith E. What is earth jurisprudence? Key principles to transform law for the health of the planet. Penn State Environmental Law Review, v. 18, p. 47-69, Fall, 2009. Disponível em: <http://papers.ssrn.com/>. Acesso em: 6 jul. 2017.

KORSGAARD, Christine M. A Kantian case for animal rights. In: MICHEL, Margot; KÜHNE, Daniela; HÄNNI, Julia (Eds.). Animal Law: developments and perspectives in the 21st Century. Zürich: Dike, 2012, p. 3-27. Disponível em: <http://www.people.fas.harvard.edu/ korsgaar/ CMK.Animal.Rights.pdf>. Acesso em: 6 jul. 2017.

KORSGAARD, Christine M. Fellow Creatures: Kantian ethics and our duties to animals. In: Peterson Grethe B. (Ed.). The Tanner Lectures on Human Values, Salt Lake City, v. 25, p. 1-37, 2005. Disponível em: <http://www.likealittledisaster.com/wp-content/uploads/2017/01/ CMK.FellowCreatures.pdf >. Acesso em: 6 jul. 2017.

LOVELOCK, James. Gaia: a new look at life on Earth. Oxford: Oxford University, 2000.

LOVELOCK, James. Gaia: alerta final. Tradução de Vera de Paula Assis e Jesus de Paula Assis. Rio de Janeiro: Intrínseca, 2010.

MARTINS, Evilhane Jum; TYBUSCH, Jerônimo Siqueira; MORELLO, Giane da Silva Ritter. As amarras do neoconstitucionalismo e as perspectivas do novo constitucionalismo latinoamericano: elementos paradigmáticos para a efetivação dos direitos humanos dos povos da América do Sul. Revista de Direito Brasileira, São Paulo, v. 17, n. 7, p. 90-107, maio/ago. 2017. Disponível em: <http://www.rdb.org.br/ojs/index.php/rdb/article/view/626/352>. Acesso em: 14 nov. 2017.

MELO, Álisson José Maia. Natureza, bem-viver e desenvolvimento com equidade: uma introdução ao novo constitucionalismo econômico latino-americano. Revista da Faculdade de Direito da UFG, Goiânia, v. 40, n. 2, p. 64-90, 2016. Disponível em: <https:// www.revistas.ufg.br/revfd/article/view/42231>. Acesso em: 8 jul. 2017.

MORAES, Germana de Oliveira; MARQUES JÚNIOR, William Paiva. A construção do paradigma ecocêntrico no novo constitucionalismo democrático nos países da Unasul. Revista de Direito Brasileira, São Paulo, v. 5, n. 3, p. 42-69, maio/ago. 2013. Disponível em: <http:// www.rdb.org.br/ojs/index.php/rdb/article/view/95/92>. Acesso em: 14 nov. 2017.

NEVES, Marcelo. A constitucionalização simbólica. 3. ed. São Paulo: WMF Martins Fontes, 2016.

NEW ZEALAND. Te Awa Tupua (Whanganui River Claims Settlement) Bill. New Zealand Legislation. Wellington, NZ: Parliamentary Consel Office, 2016. Disponível em: <http:// www.legislation.govt.nz/>. Acesso em: 8 jul. 2017. 
NUSSBAUM, Martha C. The moral status of animals. Arcus Foundation, New York, Stories of Impact, aug. 14, 2008. Disponível em: <http://beta.arcusfoundation.org.s3.amazonaws.com/wpcontent/uploads/2014/09/The_Moral_Staus_of_Animals_by_Martha_Nussbaum_2006.pdf>. Acesso em: 6 jul. 2017.

ONG PACHAMAMA. Em ação judicial inédita no Brasil, o Rio Doce, representado pela Associação Pachamama, pede o reconhecimento de seus direitos à vida e a saúde. Portal ONG Pachamama, 7 nov. 2017. Disponível em: <https://www.ongpachamama.org/single-post/2017/11/ 07/Uma-a\%C3\%A7\%C3\%A3o-pelos-rios-como-sujeitos-de-direito>. Acesso em: 14 nov. 2017.

REGAN, Tom. The case for animal rights. Berkeley, Los Angeles: University of California, 1983.

SANTA SÉ. Carta encíclica Laudato Si’ do santo padre Francisco sobre o cuidado da casa comum. Vaticano: A Santa Sé, 2015. Disponível em: <http://w2.vatican.va/content/francesco/pt/ encyclicals/documents/papa-francesco_20150524_enciclica-laudato-si.pdf >. Acesso em: 10 jul. 2017.

SANTAMARÍA, Ramiro Ávila. Los derechos de la naturaleza desde el pensamiento crítico latinoamericano. Revista Culturas Jurídicas, Rio de Janeiro, v. 4, n. 8, maio/ago. 2017.

Disponível em: <http://www.culturasjuridicas.uff.br/index.php/rcj/article/view/433/166>. Acesso em: 14 nov. 2017.

SIEMEN, Patricia. Earth jurisprudence: toward law in nature's balance. Barry Law Review, v. 11, p. 1-10, Fall 2008. Disponível em: <http://papers.ssrn.com/>. Acesso em: 6 jul. 2017. . The rights of nature. TEDx Jacksonville, 6 dez. 2013. Disponível em: <http:// tedxjacksonville.com/talks/>. Acesso em: 6 jul. 2017.

STONE, Christopher D. Should trees have standing? - Toward legal rights for natural objects. Southern California Law Review, n. 45, p. 450-501, 1972. Disponível em: <https:// enviroethics.org/>. Acesso em: 6 jul. 2017.

STUTZIN, Godofredo. Un imperativo ecológico: reconocer los derechos de la naturaleza. Ambiente y Desarrollo, v. 1, n. 1, p. 97-114, dic. 1984. Disponível em: <http://www.opsur.org.ar/ blog/>. Acesso em: 6 jul. 2017.

SUÁREZ, Sofía. Defendiendo la naturaleza: retos y obstáculos en la implementación de los derechos de la naturaleza. Caso río Vilcabamba. FES Energía y Clima, Análisis, ago. 2013. Quito: CEDA; FES, 2013. Disponível em: <http://library.fes.de/pdf-files/bueros/quito/ 10230.pdf>. Acesso em: 8 jul. 2017.

UNITED NATIONS. General Assembly A/RES/35/7. Draft World Charter for Nature. New York: UN, 1980. Disponível em: 〈http://undocs.org/A/RES/35/7〉. Acesso em: 8 jul. 2017. A/RES/37/7. World Charter for Nature. New York: UN, 1982. Disponível em: <http://undocs.org/A/RES/37/7>. Acesso em: 8 jul. 2017. 
. A/RES/63/278. International Mother Earth Day. New York: UN, 2009a.

Disponível em: <http://undocs.org/A/RES/63/278>. Acesso em: 8 jul. 2017.

. A/RES/64/196. Harmony with Nature. New York: UN, 2009b. Disponível em: <http://undocs.org/A/RES/64/196>. Acesso em: 8 jul. 2017.

. A/RES/64/253. International Day of Nowruz. New York: UN, 2010a.

Disponível em: <http://undocs.org/A/RES/64/253>

. A/RES/65/164. Harmony with Nature. New York: UN, 2010b. Disponível em: <http://undocs.org/A/RES/65/164>. Acesso em: 8 jul. 2017.

A/RES/65/309. Happiness: towards a holistic approach to development. New York: UN, 2011a. Disponível em: <http://undocs.org/A/RES/65/309>. Acesso em: 10 jul. 2017.

A/RES/66/204. Harmony with Nature. New York: UN, 2011b. Disponível em: <http://undocs.org/A/RES/66/204>. Acesso em: 8 jul. 2017.

A/RES/66/288. The future we want. New York: UN, 2012a. Disponível em: <http://undocs.org/A/RES/66/288>. Acesso em: 8 jul. 2017.

. A/RES/67/214. Harmony with Nature. New York: UN, 2012b. Disponível em: <http://undocs.org/A/RES/67/214>. Acesso em: 8 jul. 2017.

A/RES/68/216. Harmony with Nature. New York: UN, 2013a. Disponível em: <http://undocs.org/A/RES/68/216>. Acesso em: 8 jul. 2017.

. A/RES/69/224. Harmony with Nature. New York: UN, 2014a. Disponível em: <http://undocs.org/A/RES/69/224>. Acesso em: 8 jul. 2017.

. A/RES/70/1. Transforming our world: the 2030 Agenda for Sustainable Development. New York: UN, 2015a. Disponível em: <http://undocs.org/A/RES/70/1〉. Acesso em: 8 jul. 2017.

. A/RES/70/208. Harmony with Nature. New York: UN, 2015b. Disponível em: <http://undocs.org/A/RES/70/208>. Acesso em: 8 jul. 2017.

. A/RES/71/232. Harmony with Nature. New York: UN, 2016a. Disponível em: <http://undocs.org/A/RES/71/232>. Acesso em: 8 jul. 2017.

. Second Committee. A/C.2/72/L.38. Harmony with Nature. Ecuador: draft resolution. New York, UN, 2017a. Disponível em: <https://documents-dds-ny.un.org/doc/ UNDOC/LTD/N17/342/01/PDF/N1734201.pdf?OpenElement>. Acesso em: 14 nov. 2017.

. Secretary-General. A/65/314. Harmony with nature: report of the secretarygeneral. New York: UN, 2010c. Disponível em: <http://undocs.org/A/65/314>. Acesso em: 10 jul. 2017. 
. A/66/302. Harmony with nature: report of the secretary-general. New

York: UN, 2011c. Disponível em: <http://undocs.org/A/66/302>. Acesso em: 10 jul. 2017.

A/67/317. Harmony with nature: report of the secretary-general. New York: UN, 2012c. Disponível em: 〈http://undocs.org/A/67/317〉. Acesso em: 10 jul. 2017.

A/68/325. Harmony with nature: report of the secretary-general. New

York: UN, 2013b. Disponível em: <http://undocs.org/A/68/325>. Acesso em: 10 jul. 2017.

A/69/322. Harmony with nature: report of the secretary-general. New York: UN, 2014b. Disponível em: <http://undocs.org/A/69/322>. Acesso em: 10 jul. 2017.

A/70/268. Harmony with nature: report of the secretary-general. New York: UN, 2015c. Disponível em: 〈http://undocs.org/A/70/268>. Acesso em: 10 jul. 2017.

A/71/266. Harmony with nature: note by the secretary-general. New York: UN, 2016b. Disponível em: <http://undocs.org/A/71/266>. Acesso em: 10 jul. 2017.

A/72/175. Harmony with nature: report of the secretary-general. New York: UN, 2017b. Disponível em: 〈http://undocs.org/A/72/175>. Acesso em: 14 nov. 2017.

GA/10967. General Assembly adopts resolution recognizing Access to clean water, sanitation as human right, by recorded vote of 122 in favour, none against, 41 abstentions. Meetins coverage, 28 july 2010d. Disponível em: <http://www.un.org/press/en/2010/ ga10967.doc.htm>. Acesso em: 8 jul. 2017.

VICIANO PASTOR, Roberto; MARTÍNEZ DALMAU, Rubén. El nuevo constitucionalismo latino-americano: fundamentos para uma construcción doctrinal. Revista General de Derecho Público Comparado, n. 9, p. 1-24, 2011.

; _ ¿ ¿ Se puede hablar de un nuevo constitucionalismo latino-americano como corriente doctrinal sistematizada? Ponencia presentada en el VIII Congreso Mundial de la Asociación Internacional de Derecho Constitucional: constituciones y principios. Valencia: Universidad de Valencia, 2010.

WORLD PEOPLE'S CONFERENCE ON CLIMATE CHANGE AND THE RIGHTS OF MOTHER EARTH. Universal declaration of rights of mother earth. Cochabamba: WPCCCRME, 22 apr. 2010. Disponível em: <http://therightsofnature.org/wp-content/uploads/FINALUNIVERSAL-DECLARATION-OF-THE-RIGHTS-OF-MOTHER-EARTH-APRIL-222010.pdf>. Acesso em: 8 jul. 2017.

ZAFFARONI, Eugenio Raul. La Pachamama y el humano. Buenos Aires: Madres de Plaza de Mayo, 2012. Disponível em: <http://campus.integral.edu.ar/pluginfile.php/66315/mod_resource/ content/1/zaffaroni_la_pachamana_1.pdf>. Acesso em: 7 jul. 2017. 